\title{
Knutby Filadelfia: A Schismatic New Religious Movement Within the Pentecostal Context
}

\section{Liselotte Frisk}

Knutby Filadelfia, situated in Knutby just outside Uppsala, Sweden, is a small religious community with roots in the Pentecostal Movement of the early twentieth century. ${ }^{1}$ As of 2014 , it had 96 members. The congregation was structurally part of the national network the Pentecostal Movement (Pingströrelsen) until 2004, when it was expelled on the grounds that its beliefs were "unorthodox."

In January 2004, a tragic crime put this small religious community in the spotlight of media attention, which entailed the public exposure of its unique beliefs and lifestyle, including its interpretation of the Christian symbol of the Bride of Christ as a human being: Åsa Waldau. Alexandra Fossmo, the young wife of one of its pastors, Helge Fossmo, was killed by gunshot, and a young male member was seriously wounded. Pastor Fossmo was found guilty of conspiracy to murder and sentenced to life in prison. ${ }^{2}$ The investigation revealed that the man who had been shot was the husband of one of the pastor's mistresses. A young member, Sara Svensson, was convicted as the perpetrator of the shootings. She, too, had been having a romantic relationship with the pastor. The court, however,

L. Frisk $(\bowtie)$

Dalarna University, Falun, Sweden

(C) The Author(s) 2018

J. Moberg, J. Skjoldli (eds.), Charismatic Christianity in Finland,

Norway, and Sweden, Palgrave Studies in New Religions and Alternative

Spiritualities, https://doi.org/10.1007/978-3-319-69614-0_6 
ruled that Svensson had performed the crimes while heavily under the influence of the pastor, who had been sending anonymous text messages to her cell phone, urging her to perform the deed-messages she believed came directly from God. Svensson was committed to a psychiatric ward.

This study initially portrays the history, religious beliefs, and lifestyle of Knutby Filadelfia. The community is described and analyzed from a sociological perspective on new religious movements, and the theological and organizational boundaries of the Pentecostal Movement and the phenomenon of schism and expulsion will be discussed. At the end of the chapter, a lifeworld approach will be explored as an analytical perspective on the crimes in 2004.

Knutby Filadelfia has received very little scholarly attention, despite the high levels of media publicity and speculation. Sociologist Eva Lundgren wrote a book in 2008, mainly mirroring the former pastor Helge Fossmo's perspective on the events in Knutby Filadelfia. There is also a short summary of the events written by historian of religion Jonathan Peste, based mainly on journalistic accounts. Finally, Frisk and Palmer have written a paper (2015) using narrative analysis on the story of Helge Fossmo, based on an interview with the former pastor. Thus, this chapter may be said to be the first fieldwork-based portrayal of this religious group from an academic perspective. The material consists of interviews and informal conversations with members, pastors, representatives, and ex-members of Knutby Filadelfia, as well as material gathered from participant observation at Sunday services and social events, such as dinners and the Friday night coffee meeting - all conducted between the years 2011 and 2015 . The first part of the chapter describes Waldau's own story of her journey to Knutby Filadelfia, based mainly on an interview with her and a book she authored.

\section{History and Development}

Knutby Filadelfia was founded in the village of Knutby outside Uppsala in 1921 as a Pentecostal congregation (Peste 2011, 218). It remained a fairly orthodox Pentecostal organization for the first few decades. In 1985, Kim Wincent, who had attended the Bible school at Word of Life (Livets ord), became the head pastor (Lundgren 2008, 54-56). Like in many other Pentecostal congregations at the time, several of the members of Knutby Filadelfia had been in contact with the Word of Life to various degrees-a development that continued during the 1990s. There was never, however, any formal collaboration between the two groups. 
In 1992, Åsa Waldau moved to the village from Uppsala, and from that time on put her unique mark on the community. Waldau was born in 1965. She was born into a secular home, but her grandfather, Willis Säwe, with whom she had close and positive contact during her childhood, was an important figure of leadership in the early Swedish Pentecostal Movement. Waldau recalls that she had a salvation experience at the age of 16, when she accompanied a friend to a teenage camp in the Sanctification Union (Helgelseförbundet), one of the Swedish free churches. ${ }^{3}$ A little later, in the Pentecostal Movement, she discovered what she now considers to be most important to her: an emphasis on the individual's personal experience of and relationship to God, as well as closeness to Jesus. Waldau also found the Pentecostal teachings to be consistent with what was written in the Bible. Another aspect she found important was their emphasis on love and fellowship between followers. Waldau says that she had always been more attracted to the teaching to do good to one another, to create the community Jesus preached, than to the charismatic aspects of looking for "signs and miracles." Additionally, these egalitarian values were important for Waldau, the putting into practice of the idea that God's will is sought by the community as a whole, as well as the idea that everyone could find his or her own way to serve God (Interview 1).

Waldau was baptized in 1983, and after that worked with different projects within Pentecostal congregations in, for example, Laxå and Uppsala. She worked a lot with children and teenagers, but also with music, and after some time she started to teach and evangelize. Her musical style could be described as prayers to God set to music, with some similarities to the devotional songs expressed in Neo-Pentecostal contexts. Waldau says that she met some resistance in the Pentecostal Movement. According to her, it was a problem for some that too many people came to listen to her, and that too many people asked her to come and talk. Some considered her popularity a threat, and also thought her way of speaking was too direct, meaning-according to herself-her habit of being very clear about what she considered to be right and wrong, based on the Bible. When she moved to Uppsala in 1990, she started working as a children's pastor. This ended in 1992, when Waldau's husband left her for one of her best friends, resulting in a divorce. According to Waldau, the divorce prevented her from continuing as a pastor in the Pentecostal Movement in Uppsala. Additionally, she says she could not cooperate with a younger male coworker, who wanted to decide what she should do, just because she was a woman. Waldau also expresses that she was disappointed 
by the hypocrisy and power struggles she saw in the Pentecostal Movement (Interview 1). The problems between Waldau and the Pentecostal Movement are confirmed by other sources; however, these often blame Waldau for the problems (Lundgren 2008, 67).

At this point, Waldau was invited to stay in Knutby for a while, as some of her friends, who were members of Knutby Filadelfia (and were the parents of her future husband), thought that this was what God wanted her to do. After some time, she was asked to stay and work there on a continual basis. This request was to some extent influenced by a prophetic message that Knutby Filadelfia should open its doors to a female servant of the Lord who had experienced a great crisis (Interview 1). This message was allegedly received by a priest in the Church of Sweden who was visiting Knutby for a meeting (Interview 4). Hearing this, Waldau also thought it was God's will that she should stay in Knutby (Interview 1).

The congregation had 40 members in 1991 (Lundgren 2008, 55). Waldau largely had the freedom to work in the ways she thought best, and immediately started working with children and music. This was, according to Waldau, a great success. In 1994 she married Patrik Waldau who, like his parents, had belonged to the community for a long time. ${ }^{4} \mathrm{He}$ was also one of the young people she had met at Uppsala. They had two children together (Interview 1).

During the 1990s, Åsa Waldau served as a traveling evangelist within the Pentecostal Movement, venturing all over Sweden. Many of the people she met moved to Knutby after some time and developed close relationships with her. Among these new members were Helge Fossmo and Sara Svensson. In 1997, Knutby Filadelfia started a Bible school, which still exists but now has fewer participants. At that time, the Bible school consisted of one course that lasted for three months and was held annually. Participants stayed in private homes, which led some people to take such a liking to the way of life in Knutby Filadelfia that they decided to stay. Within a few years, the membership had doubled to about 100 members (Interview 1). Some of the older members did not like Åsa Waldau's new spiritual authority and left the congregation (Lundgren 2008, 68). The new community consisted mainly of young and enthusiastic people, many of whose family backgrounds were in the Pentecostal Movement (Lundgren 2008, 59).

Around the year 2000 there was a strong expectation shared by the Knutby pastors and members that Jesus would return to usher in the millennium very soon. A belief developed concerning Knutby Filadelfia's important role in the coming global events: God had a special purpose for 
this particular congregation, and a specific role for Åsa Waldau. The group waited for the return of Jesus (Informal Conversations 2). The members of Knutby Filadelfia prayed for this to happen, and they talked in this context about "coming home" and "be[ing] taken home." The concept of "coming home," used by the community in this manner, has been criticized as possibly referring to death, contributing to the notion of death as something positive, and thereby providing a context of rationalization for the later murder and murder attempts (Peste 2011, 217).

Informal conversations with members point to the death of Helge Fossmo's first wife, Heléne Fossmo, in 1999, as an event which, at least retrospectively, changed many aspects of the community's thinking (Informal Conversations 1). Heléne Fossmo was found dead in the bathtub in her own house. At the time, her death was concluded to be a tragic accident, ${ }^{5}$ but it would become important for the development of the congregation's teachings on death. The members were all relatively young, and many have since expressed that they had not thought much about death before. Now, it seemed so much closer as it had happened unexpectedly to a young person in their midst. Some thought that God's kingdom would soon come and that they would meet Heléne again, and many people in the congregation had a strong longing for this to happen. Additionally, Fossmo expressed that he had received a vision that God would take Åsa Waldau home soon, which she took seriously for some time (Interview 1).

Prophecies, visions, and demons have at times played a major role in the community's theology, as they sometimes have in Pentecostal congregations (Lundgren 2008, 61-63; Peste 2011, 219). Åsa Waldau says, however, that she resisted the excesses of searching for signs and miracles, and that the love and fellowship in the community, as well as the search for Jesus were much more central to her (Interview l). Pastor Peter Gembäck remarks that these phenomena were especially significant at the time of Helge Fossmo's pastorship (Informal Conversations 2).

The Knutby case received a tremendous amount of media attention (Norman 2007). The congregation was criticized by all corners of society, religious as well as secular. The Pentecostal Movement was quick to denounce Knutby Filadelfia. The congregation was expelled in 2004 and is not part of any network today. Åsa Waldau has expressed disappointment, because she feels that no one from the Pentecostal Movement stood up for her and Knutby Filadelfia when the media storms ensued (Interview 1). On the contrary, the spokesman for the Pentecostal Movement, Sten-Gunnar 
Hedin, was very clear that Knutby Filadelfia deviated from the Pentecostal Movement, and had nothing to do with it (Norman 2007, 28).

Åsa Waldau is no longer a pastor, but she remains a member of Knutby Filadelfia. Since 2008, she has withdrawn from leadership and lives in seclusion from the community. Waldau appeared frequently in the headlines and also live on various radio and television channels during the first few years after the event. The pressure from the events of and media storms after 2004 finally became too much, and Waldau says today that she needed to create distance between herself and people who needed her help. She also expresses disappointment in certain ex-members who have been very critical of her in the media and whom, she says, she has been prepared to give her life for. Today, she works as an artist, musician, and designer, and she says that also in these actions she aims at surrendering to God and being able to do his work (Interview 1). Although Waldau is no longer present in the everyday life of the community, her charisma is still evident in many ways. Her paintings are everywhere, as is her music, and she remains an inspiration and spiritual guide for many members.

The community has undergone significant demographic changes recently, as the number of children has increased markedly since 2004. Most children are younger than 10 years old. About 10 members have left over the last few years, some of them previously having belonged to the "inner core," such as the parents of Patrik Waldau (Informal Conversations 2).

\section{LEADERSHIP AND AUTHORITY}

Knutby Filadelfia is organized as a nonprofit organization with a board chosen by the members. The board consists of 10 elders. In 2015, all the elders were men, but a few women have also held board positions, Åsa Waldau among them. As of 2015, there are three pastors, all of whom are members of the board. The organization is democratic in the formal sense (Interview 4). However, some leaders, especially Åsa Waldau, have had informal authority, which has led some to criticize the community as undemocratic.

To an observer of the community, the influence of Waldau on Knutby Filadelfia is very clear historically but also in the present. Many of the current members have moved to Knutby because they encountered her and what they describe as her spiritual power (Informal Conversations 1). Although Waldau has a unique position in the community, there are also other strong charismatic leaders. For the teenagers, important role models 
include some of the older men, for instance Waldau's husband Patrik and the current leader Pastor Peter Gembäck (Interviews 3).

Waldau's power and authority, as well as the presumed lack of democracy, have been criticized by ex-members (Lundgren 2008, 68), and by representatives of the Pentecostal Movement (Salomonsson 2005) among others. Some of the critics have suggested that Waldau was the real destructive force in Knutby Filadelfia, and that there is a kind of "systematic error" in the structure of the group that made the crimes possible (see for example Robèrt 2005a). Regarding Waldau, it has been claimed that she has even controlled who should marry whom in the community (Lundgren 2008, 67). Waldau confirms that many people, both historically but also today, have asked her for advice regarding many different kinds of questions in life, and have also been given advice (Interview 1).

Waldau has also been criticized for statements that have been perceived as judgmental and insulting (see for instance Lundgren 2008, 88, 125). She says today that there have been things she wishes she had never said, but that she did what she felt was right at the time. She says that, like all teachers, she has had the experience of sometimes saying the wrong thing, but that this experience is part of the development on the road to becoming more mature. According to Waldau, as a teacher one needs to be brave and clearly communicate what is right and wrong. Waldau says that, during her time in the Pentecostal Movement, she sometimes had to make decisions that were not popular with everyone, as some people were more interested in their own opinions than in God. Waldau sees her own life as an attempt to live "in spirit and truth," and to the degree that she succeeds in surrendering to God, she thinks that he is able to act through her and her words; God works through the human conscience and the inner urge to act and talk. The human interpretation, however, can be wrong sometimes, which is later shown "by the fruit" (Interview 1). It is clear that Waldau perceives herself, as do her followers, as an instrument of God and, although today there are no formal structures for her authority, her advice seems to be often sought, albeit in informal ways.

\section{BELIEFS}

The main part of Knutby Filadelfia's theology conforms to classic Pentecostal and Charismatic currents in the latter part of the twentieth century. During this time, a fertile Christian milieu was significant, with influences from several orientations. In his book The Globalisation of 
Charismatic Christianity, Simon Coleman (2000) describes this as alobalized scene with Neo-Pentecostal as well as fundamentalist currents. Significant orientations were the Faith Movement and the Toronto Blessing (Coleman 2000, 23-28). In Sweden, as elsewhere, the 1960s and 1970s were times of Charismatic revival within older churches. The Swedish Faith Movement could be seen as part of the wider PentecostalCharismatic landscape, with elements from Neo-Pentecostal groups in the United States, but also built on earlier revivals. The Word of Life, the most important Faith Movement church in Sweden, was established in 1983 by the former state church priest Ulf Ekman. There were also other Charismatic groups and currents at play in Sweden, which had emerged in the 1960s and 1970s. Two examples are the Maranata Movement (Maranatarörelsen), which came out of a minor Pentecostal revival, and the Jesus Movement (Coleman 2000, 89-90). In the broader PentecostalCharismatic context, neither the imminent return of Christ, nor God giving humans very concrete signs, were alien ideas.

However, Knutby Filadelfia also has some unique traits. A distinct characteristic is its continuous re-evaluation of previous theological positions where the members bring up subjects for discussion, study the scriptures in search for what the Bible "says," and formulate new theologies. In this way, their doctrine is dynamic and sometimes changes.

Knutby Filadelfia's most original, heterodox teaching is the idea of Åsa Waldau as the Bride of Christ. ${ }^{7}$ This belief originated in an issue brought up for discussion during the late 1990s, namely of whether the Bride of Christ really should be interpreted as the Church—the Body of Christ—as most Christians see it, or if it might be a human woman, an otherwise very unusual interpretation. Pastor Helge Fossmo's statement to Waldau is now quite famous: "If the bride of Christ is a woman, then it must be you." Today, Waldau says she considered it her duty to look within her if there could be any truth to this suggestion and that she did reflect upon this matter for a while. She points out, however, that the whole idea came from Helge Fossmo and not from her (Waldau 2007, 237-244). The fact that she tried this belief for a while also had the effect that she withdrew from the daily tasks of the community for some time. It seems that the notion of Waldau as the Bride of Christ was unknown to the main body of the congregation, and known only to the closest group, comprised of less than a dozen people (Informal Conversations 2). Others may have heard rumors and hints, and drawn their own conclusions. Considering the negative attention this idea has received in Swedish media, it is unsurprising that the community now seeks to downplay the importance of this belief. 
Between 2008 and 2009, another theological question came up for discussion and reassessment: the Trinity. Pastor Peter Gembäck explains that Knutby Filadelfia has opened up regarding the question of the humanity of Jesus. He thinks Jesus may make more sense as a human being, as a role model and example, than as a distant God. In the Christian context, this question is explosive, and Knutby Filadelfia has not taken any formal stand. The pastors and members continue to reflect on the true significance of the Trinity (Interview 4). It may be noted that humanization of Jesus goes well together with the process of reflecting on whether or not the Bride of Christ might be a human individual.

Knutby Filadelfia has also taken another stand that distinguishes it from the traditional Pentecostal churches and denominations regarding a lifestyle issue: wine drinking. In accordance with most other Christian orientations, the practitioners believe that it is not a sin to have one or two glasses of wine now and then, which most of them also do. In their view, there is nothing in the Bible indicating that wine consumption should be forbidden (Informal Conversations 2).

\section{LIFESTYLE}

Knutby Filadelfia is a very tight-knit community. Its foundation according to Åsa Waldau is, she says, the love and fellowship between Christian brothers and sisters, and worshiping God (Interview 1). Although families mostly live in their own houses, they often have meals together, spend time at each other's houses, and help each other with various tasks. Children sometimes sleep over in other houses than that of their parents, and single members sometimes share house with a family. These relatively close relationships between members has been criticized by psychiatrist Rigmor Robèrt, who interprets this semi-communalism as artificial intimacy and an insidious strategy for social control (Robèrt 2004). These close relations also create a tight community with boundaries dividing it from mainstream society, some of which are geographic, and others social.

The gender roles in the community generally conform to conservative, traditional Christian norms: The man should have the ultimate responsibility for and authority in the family, the woman should be cared for and provided for by the man. In the words of Åsa Waldau: the man should be "male" and the woman "female" (Waldau 2007, 187-191). This, however, has not affected the members' professional lives. Women in the community work outside the household to about the same extent as their 
counterparts in mainstream society. Regarding sexuality, the group has a positive approach to sexuality within marriage, but prohibits all forms of pre- and extramarital relations. There have, however, been examples of extramarital relations in the group, as seen in the case of Helge Fossmo. Fossmo himself motivated this by divine revelation and considered his relationship to Svensson to have spiritual meaning; their sexual relations were part of a form of "spiritual warfare" they were engaged in together (Lundgren 2008, 150-152).

As mentioned, there are many small children in the congregation today, and the children are often encouraged to develop close bonds to several adults beside their parents. Critics have highlighted possible negative consequences for the children, saying for example that this is part of a broader pattern of cultivation of artificial closeness among the members, and that physical and psychological abuse is common. Robèrt writes that a kind of exorcism is carried out, during which leaders discipline the children (Robèrt undated-a, b; 2005b). ${ }^{8}$ Following the events of 2004, there have also been social investigations involving families in the community. In one case, during a custody conflict, a husband who was still a member of the group was reported to the police by his ex-wife, who had left the group, who had left the group, for physical abuse of their child. However, he was found not guilty. Three families have furthermore been reported to the local authorities for mistreating their children-among them Åsa Waldau's own family. The families were investigated and no evidence of abuse was found. ${ }^{9}$

In another case, two members who worked as teacher and assistant at the public school in Knutby were convicted on charges of physical violence towards their pupils. One was for pinning a child to the ground, the other for throwing snow at a child. According to an interview with the teacher involved in one of the cases, the boy held down had severe problems and was aggressively violent, and there was no other way to handle him (Interview 2 ). At the time of the crime, there were eight people from Knutby Filadelfia working at the school in different roles. All of them lost their jobs at the time, but were later exonerated, and some returned to jobs under the same municipal employer, albeit in other schools (Interview 2; Interview 4).

\section{The Boundaries of the Pentecostal Movement}

Before May 2004, the Pentecostal Movement in Sweden consisted of a network of independent but cooperating congregations. In that year, however, the movement transformed into a judicially religious denomination (trossamfund): Pingst-Fria församlingar i samverkan (PFFS) (Wahlström 
2007, 316), in English, The Pentecostal Alliance of Independent Churches (PAIC). This development from network to denomination may have been partly influenced by the violent events in Knutby Filadelfia earlier the same year, although the development towards a national organization started earlier, and has parallels in the other Nordic countries, as discussed by Teemu T. Mantsinen in this volume. Two of the arguments in favor of a defined denomination were that the Pentecostal Movement would be in a stronger position to communicate with mainstream society, and that it would be clear who and which congregations represented the community. Moreover, it would be possible to ostracize "deviating" congregations (Wahlström 2007, 314). Before this, there was no formal procedure for accepting or ostracizing congregations in the network; it was more of an informal process. Lewi Pethrus himself, one of the most prominent leaders in the early Pentecostal Movement, had been disinclined to organize a denomination (Carlsson 2008, 71). The ideal of the Pentecostal Movement from the very beginning was that there should be no central organization and that the local congregations should be free and independent, but united through collaboration (Carlsson 2008, 71; Lindberg 1991, 263). On PAIC's website (2014), it says that it is necessary to encourage and give space to the life, integrity, uniqueness, and development of each local congregation, thus allowing room for certain differences between the congregations.

The Pentecostal Movement's “Marriage Committee” (Vigselnämnden) is an institution that has played a critical role in determining which local bodies should be perceived as Pentecostal congregations. This special committee determines whether local pastors should be given the right to perform juridically valid wedding ceremonies (Interview 5; Lindberg 1991, 274-276). ${ }^{10}$ Besides, the list of congregations published each year in the Pentecostal Movement's yearbook was the go-to reference work for finding out congregations were seen as parts of the Movement. It is evident that Knutby Filadelfia, prior to 2004, was one of many Pentecostal congregations included in the yearbook's list, and the Marriage Committee had granted Pastor Helge Fossmo the right to perform wedding ceremonies.

An article published in the Pentecostal Movement's 2005 yearbook, written by the Pentecostal director in Uppsala, Dan Salomonsson, points out that there had been tensions and questions around the congregation in Knutby for a few years. He refers to its isolation, mentioning that the pastors from Knutby did not participate in collective events, and that a group of concerned relatives had contacted the Pentecostal Movement about the difficulties of keeping in contact with the members in Knutby 
Filadelfia. Representatives of the Pentecostal Movement had also noticed that some of the older members of Knutby Filadelfia had left the group, due to the changed leadership style introduced with Åsa Waldau. Thus, even before the murder, representatives of the Pentecostal Movement had expressed and voiced concerns for Knutby Filadelfia (Salomonsson 2005). A contributing component was probably that Waldau had left the congregation in Uppsala under turbulent circumstances. Later in the article, Salomonsson states that in 2004, other evidence surfaced, showing that Knutby Filadelfia deviated from the "natural orientation" of a Christian (i.e., Pentecostal) congregation. Salomonsson cites amongst these the belief that the Bride of Christ could be a human being, materialized as Åsa Waldau; promiscuity in the community; alcohol consumption; the members' way of bringing up children; ${ }^{11}$ the congregation's lack of openness towards the wider community; and the absence of a democratic structure (2005).

As part of the exclusion process, the Pentecostal Movement withdrew the right to perform marriages from Fossmo in June 2004 (Salomonsson 2005 ). Since then, Knutby Filadelfia has no longer been mentioned in the Pentecostal yearbook - an act of exclusion that could be interpreted as approximate to expulsion, since the Pentecostal Movement at that time lacked a formal mechanism of either affiliation or expulsion. This was not the first time the Pentecostal Movement had distanced itself from local religious bodies, and the exclusion of Knutby Filadelfia follows historical patterns. Alf Lindberg mentions a few examples from the 1950s, and the case of Södermalm's Free Congregation (Södermalms Fria Församling) in 1988. ${ }^{12}$ Lindberg gives no specific reasons for the conflicts, except that in 1958 the pastor in Trollhättan had collaborated with pastors with whom there were "doctrinal disagreements." The Marriage Committee stated that Södermalm's Free Congregation and its pastors had shown in word and deed that they did not wish to be part of the Pentecostal Movement (Lindberg 1991, 276-283). The words and deeds corresponded to conformity with Word of Life ideals, and Ulf Ekman had also been invited to preach there (Coleman 2000, 91, 220). According to an article in the 1989 yearbook, the congregation also arranged competing conferences that were scheduled to take place at the same time as the significant Pentecostal conferences (Pingströrelsens årsbok 1989, 6). As with Knutby Filadelfia, the Marriage Committee played a central role in withdrawing the grant to perform marriages from certain pastors, and these local congregations were wiped out of the yearbook (Lindberg 1991, 276-283). 


\section{Tradition Versus Novelty, Schisms, and "Sects"}

Religion tends to be expressed in traditional, as well as new and creative ways. An often emphasized component in religious innovation is the charismatic leader or charismatic authority (Barker 2004). The leading thinker on charismatic authority, Max Weber, also introduced the sociologist church/sect typology $(1978,1164)$, later developed by other sociologists, as discussed below. Weber considered charismatic leaders to be potential carriers of creativity, and as key to cultural and social change-religiously, politically, and economically. Charismatic authority is therefore a challenge to existing institutions, as it tends to change, undermine, and destroy them. It may thus also lead to derangement and deviance (Weber 1968, $\mathrm{xix}-\mathrm{xx})$. Concerning the case of Knutby Filadelfia, it is clear that Åsa Waldau holds charismatic authority in the Weberian sense. In Weber's terms, she is considered by the followers to possess "a certain quality of an individual personality by virtue of which [s] he is set apart from ordinary men and treated as endowed with supernatural, superhuman, or at least specifically exceptional qualities" (Weber 1964, 358). Waldau is also the initiator of the creative theological elements that developed in Knutby Filadelfia. An important exception is the Bride of Christ doctrine, which was reportedly initiated by Helge Fossmo, but revolves around the charisma of Waldau. The institutionalized Pentecostal Movement considers the doctrine unorthodox.

American sociologists Rodney Stark and William Sims Bainbridge, as well as British sociologist Eileen Barker, have taken interest in innovation in religious organizations. Barker discusses tradition versus novelty in the article "What Are We Studying? A Sociological Case for Keeping the "Nova"' (2004). While religious creativity mostly has roots in older traditions, what Barker calls "new religious movements", or first-generation movements, ${ }^{13}$ also exhibit characteristics that could in some sense be viewed as "new." Barker lists some of them as charismatic authority, external antagonism, atypical membership (attracting members from one strata of the population, for example, of a particular age or class), and rapid change. Knutby Filadelfia may be said to conform to several of these. Rarely has such a small religious group in Sweden been subjected to a level of external antagonism close to that of Knutby Filadelfia, which featured in media headlines daily or weekly for several years.

Living in a highly demanding religious community with a strong sense of communal identity naturally generates identification of one's group as 
being special compared to mainstream society, and a certain degree of separation between "us" and "them." For many of the members, it seems that the media attention has strengthened their identification with the community. Also, the members moving to, and settling in, Knutby Filadelfia were demographically in the same phase of life, mostly between 20 and 30 years of age. Several of them were second- or third-generation members of well-known Pentecostal families in Sweden, which may also have contributed to the antagonism demonstrated towards the group by some of their parents. Atypical membership-related practices are also demonstrated in the recent trend of having children in the community, as the next phase in life. Lastly, the congregation has changed rapidly in the last few years, changes rooted in its charismatic leadership structure, but also in the tragic events of 2004. Additionally, Barker identifies several elements as typical of new religious movements: enthusiasm, a strong sense of taking religion seriously, a common expectancy of dramatic changes in the future, as well as social or geographical boundaries created to keep the members separate from the world outside. To a certain extent, all these characteristics seem to apply to Knutby Filadelfia: The lifestyle of the community, which is geographically separated from the rest of society, requires deep religious commitment and high levels of participation, the combination of which results in a strong sense of community that generates social boundaries. Prior to the turn of the millennium, there was considerable expectation that Jesus would return very soon, although this characteristic is less prominent today.

Other aspects of Barker's work are less obviously applicable. Barker uses the phrase "first-generation movements," a concept that cannot be unequivocally applied to Knutby Filadelfia: The members who moved to Knutby after having met Waldau did not conceive of themselves as "converting to a new religion." At the time, Knutby Filadelfia was part of the Pentecostal Movement. The members' own understanding of their lifestyle was, and generally remains, that it was an imitation of that of the first Christians, which is not uncommon in Pentecostal groups. The case of Knutby Filadelfia and the Pentecostal Movement could better be described as a schism that happened gradually with the involvement of Åsa Waldau, and came to a final break in 2004. Barker writes that charismatic leadership is often especially important in those new religious movements that are created as an effect of schism (Barker 2004), and this seems to correspond to the developments in Knutby Filadelfia as well.

In several of their works, Stark and Bainbridge discuss religious novelty from a different perspective than Barker's, using the traditional sociological 
terms "sect" and "cult." Schismatic groups are key phenomena in their conceptualization. According to Stark and Bainbridge, sects, like cults, are in a state of relatively high tension with their surrounding sociocultural environment, but have prior ties to another religious organization. Furthermore, they are founded by persons who have left another religious body for the purpose of establishing the sect. They apply the term sect, therefore, only to schismatic movements (Stark and Bainbridge 1985, 25). Waldau's criticism of the Pentecostal Movement is typical of sectarian deviation: corruption, hypocrisy, and deviance from "true" religion. According to Stark and Bainbridge's conceptualization, Knutby Filadelfia is a typical case of sectarian religious revival.

The stance taken by the Pentecostal Movement regarding Knutby Filadelfia helps it distinguish itself from the crimes happening in Knutby, as well as affirming its law-abiding identity. Even before the crimes in 2004, however, there had been doubts and hesitations about some of Knutby Filadelfia's characteristics. The reaction to the crimes from the Pentecostal Movement thus also served the purpose of reaffirming its boundaries and of branding unacceptable theological traits and lifestyles as non-Pentecostal.

\section{The Crimes in Knutby Filadelfia According to A Lifeworld Perspective}

Globally, there have been several incidents connecting religion and violence in recent years, in some unfortunate cases leading to both murder and collective suicide (see Lewis 2011). In several cases, violence has been conducted by one or a few individuals, not involving the whole group, and in some of them the members have been involved to different degrees. Like in Knutby Filadelfia, religious motives may also coincide with either personal motives or, as elsewhere, with political motives.

One important question is to what extent the theology or the religious group as a whole is to blame for violent events, the answer to which certainly varies between individual cases. In the case of Knutby Filadelfia, there have been some attempts to hold the entire group responsible for the crimes. In particular, the narrative created by Fossmo in collaboration with his psychotherapist (Frisk and Palmer 2015), and recapitulated by Eva Lundgren (2008), creates a picture of Åsa Waldau as the malicious driving force, and of the theology and lifestyle of Knutby Filadelfia as a 
blueprint for the crimes. This picture, which has been widely spread in Swedish media, exhibits many similarities to common anticult representations of new religious movements, thus drawing on larger cultural narratives. ${ }^{14}$ Helena Norman, investigating the media reports on the Knutby case, has found that in the media, (especially tabloid papers) the crimes were linked to the congregational milieu and the religion, rather than to individuals $(2007,17)$. The individuals involved in the events were represented in accordance with stereotypic narrative roles or cultural archetypes, whereby Waldau ("Bride of Christ") occupies the role as the mysterious "witch," Fossmo (often referred to as "the Sex Pastor") as the "villain," and Svensson ("the Babysitter") as the innocent and manipulated "victim"-all of whom are described with different attributes that correspond to their respective archetypical roles (Norman 2007, 37-65). Norman also writes about the "sect discourse," a dominant and favored discourse in the media reports about Knutby Filadelfia, and how it was constructed by means of statements from "sect experts," defectors, the Pentecostal Movement, and the media's own voices (Norman 2007, 68).

A more fruitful approach would take into account both individual perspectives and the broader religious context. Individuals construct, experience, and interpret their lives in different ways, as part of mutual relationships with other people and the broader social group, as well as in the wider societal context. An analytical concept that may be useful for this approach is that of the "lifeworld." 15 Originating in Husserl's phenomenological perspective, it was further developed in different directions by, for example, Alfred Schütz and Jürgen Habermas (Lotz 2001, 74-75). The lifeworld is, in short, our socially constructed, lived world. Different people may, however construct a variety of individual lifeworlds. Lifeworlds then, are both shared and individual. Dahlberg et al. write that our behavior, personal actions, and individual ways of being result from our own personal space in the world, which can be described as one's own entry to a common and shared world $(2008,39)$. Didactics researcher Cecilia Nielsen describes humans as active subjects in their lifeworld, experiencing and interpreting objects, events, and relations in various ways and giving them different kinds of meaning and significance. Each individual constructs, perceives, and experiences his or her own lifeworld, although this is also based on corporeality, space, time, and intersubjectivity. In other words, our comprehension is spatially and temporally bound. Human beings are parts of contexts, natural as well as cultural, in which their experiences and actions become meaningful. As the world is intersubjective, we 
are continuously in relation with and dependent on other people who also contribute to shaping those contexts (Nielsen 2013, 29-36).

In a small group like Knutby Filadelfia, different individuals construct and perceive the world through slightly different lifeworlds; these undoubtedly share many features but diverge on others. In all religious groups, there are several layers and levels of participation. This opens up spaces for the existence of different lifeworlds relating to each respective subgroup, even within the same community. From this perspective, it is only natural that the separate subgroups of Knutby Filadelfia embraced realities that diverged from each other to some extent. The members closest to Åsa Waldau, for example, may have taken part in the teaching of the Bride of Christ doctrine, while members in the outer circle of the community remained unfamiliar with it. A promiscuous lifestyle, usually categorized as sinful in Pentecostal and many other Christian groups, was legitimized as divinely sanctioned and may have been a natural component of the lifeworlds of Helge Fossmo and some of the women close to him before 2004. Meanwhile, other members may have been ignorant of this feature. As for Sara Svensson, her closeness to, and shared lifeworld with Helge Fossmo, were combined with the significance given to prophecies and signs in the congregation at the time. This combination may have made it seem natural to her that God would communicate with her via text messages on her cell phone, asking her to sacrifice people, with the Old Testament narratives as cultural models.

It seems probable that the crimes committed by Fossmo and Svensson could only have been committed in a very specific context, here provided by the religious group that both of them belonged to. Supporting influences in this context could, for example, have been the story from the Old Testament of God asking Abraham to sacrifice his son Isaac (Genesis 22). ${ }^{16}$ The conjunction of this with several other beliefs may have reinforced this lifeworld: for example, the belief that God communicates with human beings through dreams or prophecies; and the belief in charismatic leaders, which provided fuel for the destructive pattern of the relationship between Fossmo and Svensson. In combination with the theological space in the community given to death after the demise of Fossmo's first wife, these factors are likely to have paved the way for the destructive relationship between Fossmo and Svensson. The notion of "coming home" may, for Svensson in co-construction with Fossmo, possibly have made sense when interpreted as death, thus contributing to the tragedy. For other members however, the meaning of those words would have been completely different. 
Thus, the combination of the two individuals Fossmo and Svensson, as well as the reality they constructed together, on the basis of cultural elements current in their religious community, were certainly necessary factors in the crimes. More research is needed on the history and theology of Knutby, but based on what is currently known, it can be argued that the tragic crimes emerged out of a folie à deux relationship that developed between Helge Fossmo and Sara Svensson, and their idiosyncratic interpretations of the social and religious reality constructions of Knutby Filadelfia.

\section{CONCLUSION}

The Pentecostal Movement has distanced itself from local congregations several times during its history. An early example was in the 1950s, when a congregation in Trollhättan was excluded. In the 1980s, Södermalm's Free Congregation, with its connection to the Faith Movement, was the target, and in 2004 it was Knutby Filadelfia-the focus of this study. There has obviously been a continuous need to keep up boundaries as to what should or should not be considered part of the Pentecostal Movement. With its historical loose structure, however, there have been difficulties in expelling local congregations that do not live up to the movement's standards. The only means available to do this have been to withdraw the rights of local pastors to conduct marriages, and exclude congregations from the list of Pentecostal congregations provided in yearbooks. In the case of Knutby Filadelfia, both means were employed.

Even before the crimes of 2004, tensions were apparent in the Pentecostal Movement. Standard components of religious novelty, such as charismatic authority, external antagonism, atypical membership, rapid change, strong enthusiasm, an expectation of dramatic changes in the future, and boundaries to keep the members separate, all conform to the practices of Knutby Filadelfia. As such, this case is not unique, but a textbook example of a new religious movement or, in a sociological and nonpejorative sense, a sect, and a manifestation of how religious innovation is ordinarily constructed and expressed. As such, Knutby Filadelfia, with its unique belief system and lifestyle, can be considered as originating from a sectarian schism with the Pentecostal Movement, under the charismatic leadership of Åsa Waldau.

As for the crimes, there are no indications that they should be attributed to the religious group per se. Rather, the crimes seem connected to the 
unique lifeworld created by the two persons involved in the crimes-a lifeworld that also featured components from their wider religious context. The tragic outcome then, can be considered as the result of two specific individuals' co-construction of a destructive reality in their particular interpretations of specific, but not uncommon, religious components.

\section{Notes}

1. Since autumn 2016, Knutby Filadelfia has been rapidly changing. The charismatic leader Åsa Waldau has left the group.

2. The Swedish term is anstiftan till mord, which means that someone persuades or forces another person to kill (incitement to murder). The closest equivalent in the English legal vocabulary is "conspiracy to murder."

3. The free churches in Sweden are a group of religious organizations outside the (former) state church, which have roots in revivalist currents from the nineteenth and twentieth centuries. The Pentecostal Movement is one of the free churches, and until 1994 "The Sanctification Union" (Helgelseförbundet) used to be another one-since 1997 this has been part of Interact (Evangeliska Frikyrkan).

4. Patrik Waldau is ten years younger than his wife, and was 18 at the time of the wedding. This fact has caused a lot of criticism and speculations (see for example Lundgren 2008, 67). However, cultural gender expectations need to be taken into consideration concerning this criticism. The opposite situation, a woman ten years younger than the man, would hardly cause any reactions in Swedish culture. The couple are still married after 20 years.

5. In 2004, Helge Fossmo was also tried for the murder of his first wife, but was not convicted. The judge decided that there was not sufficient evidence (Peste 2011, 218).

6. John 4: 24: this expression is often used in Pentecostal contexts.

7. See 2 Corinthians 11: 2 and Revelation 21: 9-27.

8. This is forcefully denied by representatives and members of Knutby Filadelfia, and also by some ex-members.

9. This information was provided by Pastor Peter Gembäck and I have seen the written record of formal decision taken by social authorities regarding one of the families.

10. Concerning the other free churches, it is the denomination as such which is granted such rights, and it thereafter grants this right to pastors in the congregations. As the Pentecostal Movement was not organized as a denomination institutionally speaking, a special office, "the Marriage Committee" (Vigselnämnden), was created within the Pentecostal Movement, with the mission to grant individual pastors the right to perform marriages (Lindberg 1991, 274). 
11. Salomonsson does not specify what he means by this, but it is probably the lifestyle of closeness between the members which means that the children are sometimes taken care of by other adults than the parents (to a greater extent than in mainstream society), and the alleged physical and psychological abuse referred to earlier in the chapter.

12. This congregation has since been readmitted to PAIC.

13. Barker discusses first-generation movements in general, but most of her research concerns new religious movements that became prominent in the 1960s and 1970s, such as the Unification Church (The Family Federation), ISKCON, the Church of Scientology, and the Children of God (The Family International).

14. A report from the National Board of Forensic Medicine suggests that Fossmo needs to develop insights about his personality deficiencies and nuance the picture he maintains of being a victim of "sect disease" (Rättsmedicinalverket, June 17, 2014).

15. There are many elaborations and historical contextualizations of this concept. See for instance Lotz (2001) for a brief summary.

16. This is a reflection Svensson herself seems to have made (Cristiansson 2004, 20-21).

\section{REFERENCES}

Barker, Eileen. 2004. What Are We Studying? A Sociological Case for Keeping the 'Nova'. Nova Religio 8: 88-102.

Carlsson, Bertil. 2008. Organisationer och beslutsprocesser inom Pingströrelsen. Skrifter utgivna av Insamlingsstiftelsen för pingstforskning, no. 1.

Coleman, Simon. 2000. The Globalisation of Charismatic Christianity: Spreading the Gospel of Prosperity. Cambridge: Cambridge University Press.

Cristiansson, Terese. 2004. Himmel och helvete: Mord i Knutby. Stockholm: Bokförlaget DN.

Dahlberg, Karin, Helena Dahlberg, and Maria Nyström. 2008. Reflective Lifeworld Research. 2nd ed. Stockholm: Studentlitteratur.

Frisk, Liselotte, and Susan Palmer. 2015. The Life Story of Helge Fossmo, Former Pastor of Knutby Filadelfia, as Told in Prison: A Narrative Analysis Approach. International Journal for the Study of New Religions 6 (1): 51-73.

Lewis, James R., ed. 2011. Violence and New Religious Movements. Oxford/New York: Oxford University Press.

Lindberg, Alf. 1991. Förkunnarna och deras utbildning: Utbildningsfrågan inom Pingströrelsen, Lewi Pethrus ideologiska roll och de kvinnliga förkunnarnas situation. Lund: Lund University Press.

Lotz, Thomas A. 2001. 'Lifeworld': A Philosophical Concept and Its Relevance for Religious Education. In Towards Religious Competence: Diversity as a Challenge 
for Education in Europe, ed. Hans-Günther Heimbrock, Christoph Th. Scheilke, and Peter Schreiner, 78-84. New Brunswick/London: Transaction Publishers. Lundgren, Eva. 2008. Knutbykoden. Stockholm: Modernista.

Nielsen, Cecilia. 2013. Att forska om människors levda värld—en livsvärldsansats. In Barn- och ungdomsforskning: Metoder och arbetssätt, ed. Soly Erlandsson and Lena Sjöberg, 29-46. Lund: Studentlitteratur.

Norman, Helena. 2007. Religion som medieberättelse: Expressens rapportering om Knutbyfallet. Uppsala: Uppsala Universitet, religionshistoriska avdelningen.

Peste, Jonathan. 2011. Murder in Knutby: Charisma, Eroticism, and Violence in a Swedish Pentecostal Community. In Violence and New Religious Movements, ed. James R. Lewis, 217-229. Oxford: Oxford University Press.

Pingst - Fria församlingar i samverkan 2014. http://www.pingst.se/. Accessed 5 Sept 2014.

Rättsmedicinalverket. 2014. rapport 2014-06-17, dnr G 2014-Y0005.

Robèrt, Rigmor. 2004. Kristi brud bör träda fram. Expressen, April 8.

. 2005a. Kristi bruds hemliga profetia ger förklaringar till mordet i Knutby. Dagens medicin, November 23. http://www.dagensmedicin.se/artik$\operatorname{lar} / 2005 / 11 / 23 /$ kristi-bruds-hemliga-profetia-ger-forklaringar-till-mordet-iknutby-/. Accessed 28 Nov 2015.

—. 2005b. Barnmisshandel i Knutby församling. Expressen, October 18. http://www.expressen.se/debatt/barnmisshandel-i-knutby-forsamling/. Accessed 28 Nov 2015.

—. undated-a. Knutby del 7: Åsa Waldaus hemliga självprofetia. Magasinet Paragraf.https://www.magasinetparagraf.se/nyheter/knutby-artikel/42918del-7-asa-waldaus-hemliga-sjalvprofetia/. Accessed 28 Nov 2015

—. undated-b. Barnen i Knutby. Magasinet Paragraf. https://www.magasinetparagraf.se/nyheter/kronikor/43420-barnen-i-knutby/. Accessed 28 Nov 2015.

Salomonsson, Dan. 2005. Tragedin som skakade Knutby. In Pingströrelsens årsbok 2005, 8-9. Stockholm: Pingströrelsens informationscentrum.

“Södermalmskyrkan mister vigselrätt.” 1989. Pingströrelsens årsbok 1989, 6. Stockholm: Pingströrelsens informationscentrum.

Stark, Rodney, and William Sims Bainbridge. 1985. The Future of Religion: Secularization, Revival, and Cult Formation. Berkeley/Los Angeles/London: University of California Press.

Wahlström, Magnus. 2007. Fria församlingar och starka organisationer: Gemensamma verksamheter alternativ till samfund. In Pingströrelsen: Verksambeter och särdrag under 1900-talet, ed. Claes Waern and Jan-Åke Alvarsson, vol. 2, 301-316. Örebro: Libris förlag.

Waldau, Åsa M. 2007. Kristi brud—vem kan man lita på? Skara: Heja Sverige ABM.

Weber, Max. 1964. The Theory of Social and Economic Organization. Edited and with an introduction by Talcott Parsons. New York: The Free Press. 
1968. Max Weber on Charisma and Institution Building: Selected Papers. Edited and with an introduction by Shmuel. N. Eistenstadt. Chicago/London: University of Chicago Press

- 1978. Economy and Society: An Outline of Interpretive Sociology. In , ed. Guenther Roth and Claus Wittich, vol. 2. Berkeley/Los Angeles: University of California Press.

\section{INTERVIEWS AND INFORMAL CONVERSATIONS}

Informal Conversations 1: Different members of the community 2011-2014. Notes were taken.

Informal Conversations 2: Pastor Peter Gembäck, 2011-2015. Notes were taken and the content has been checked with the Pastor.

Interview 1. Interview with Åsa Waldau, May 28, 2014.

Interview 2. Anonymized interview with a member, May 29, 2014.

Interview 4. Telephone interview with Pastor Peter Gembäck, July 22, 2015.

Interview 5. Telephone interview with Magnus Wahlström, the Pentecostal Movement, September 3, 2014.

Interviews 3. Several anonymized interviews with teenagers in Knutby Filadelfia, May 28-30, 2014, for the project Children in Minority Religions, sponsored by the Swedish Research Council.

Open Access This chapter is distributed under the terms of the Creative Commons Attribution 4.0 International License (http://creativecommons.org/licenses/ by $/ 4.0 /$ ), which permits use, duplication, adaptation, distribution and reproduction in any medium or format, as long as you give appropriate credit to the original author(s) and the source, provide a link to the Creative Commons license and indicate if changes were made.

The images or other third party material in this chapter are included in the chapter's Creative Commons license, unless indicated otherwise in a credit line to the material. If material is not included in the chapter's Creative Commons license and your intended use is not permitted by statutory regulation or exceeds the permitted use, you will need to obtain permission directly from the copyright holder.

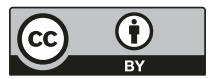

